\title{
Multi-year study of the effects of Ulva sp. blooms on eelgrass Zostera marina
}

\author{
Suzanne V. Olyarnik ${ }^{1, *}$, John J. Stachowicz ${ }^{2}$ \\ ${ }^{1}$ Bodega Marine Reserve, University of California Davis, PO Box 247, Bodega Bay, California 94923, USA \\ ${ }^{2}$ Evolution and Ecology, University of California Davis, One Shields Avenue, Davis, California 95616, USA
}

\begin{abstract}
Macroalgal blooms have contributed to declines in foundation species such as corals and seagrasses across the globe. Most studies of macroalgal bloom effects on seagrasses focus on the short-term effects, and have been conducted in locations that already begun the shift to macroalgal dominance, usually due to eutrophication. Our goal was to determine the degree to which the timing and magnitude of ephemeral, green macroalgal blooms (Ulva sp.) vary in Bodega Bay, California, USA, where there is little evidence for eutrophication, and how such blooms affect eelgrass Zostera marina. Over $38 \mathrm{mo}$, we conducted (1) an unmanipulated control treatment, and 3 manipulative treatments: (2) Ulva removal, (3) ambient Ulva, and (4) doubleambient Ulva (' $2 \times$ '). We observed 4 blooms of varying magnitude and duration, ranging from $<0.5$ to $>4 \mathrm{~kg} \mathrm{~m}^{-2}$. It was only during the largest bloom in 2006 (peak density 8 times that of the smallest observed bloom) that we saw a significant effect on eelgrass, resulting in declines in shoot density of $>50 \%$ that persisted for 4 to 6 mo. During this time, the $2 \times$ treatment reduced shoot biomass by up to $90 \%$, an effect that persisted for up to 9 mo. Ulva did not affect rates of individual shoot growth, reproductive shoot density, epiphyte load, or sediment organic content at any time during the experiment, suggesting the effect occurs through shoot mortality and reduced shoot production. Interannual variation in the magnitude timing and duration of algal blooms is large and can dramatically alter the effects of blooms on eelgrass. These factors must be considered when interpreting the results of experimental algal additions.
\end{abstract}

KEY WORDS: Seagrass $\cdot$ Macroalgal blooms $\cdot$ Species interactions $\cdot$ Foundation species

\section{INTRODUCTION}

Dramatic increases in the abundance of fastgrowing macroalgae have been implicated in many community shifts in coastal systems across temperate and tropical regions. Macroalgal blooms have contributed to the worldwide decline in major foundation species such as corals (Lapointe 1997, McClanahan et al. 2003), and seagrasses (Holmquist 1997, 2003, Hauxwell et al. 2001, 2003, Nelson \& Lee 2001, Cummins et al. 2004, Irlandi et al. 2004). Because of their effect on species that form the habitat on which associated animal species depend (Valiela et al. 1992, Diaz \& Rosenberg 1995, Raffaelli et al. 1998, Deegan et al. 2002, Cardoso et al. 2004), these changes could have community-wide implications. Furthermore, the high turnover rate and lability of macroalgal biomass can also alter rates of fundamental ecosystem processes such as carbon fixation, consumption, decomposition, storage, and export (Hauxwell et al. 2003).

Seagrasses are marine angiosperms most often found in the shallow waters of relatively wave-protected locations such as estuaries and bays, where they are the dominant primary producers. Only recently, as recognition of widespread seagrass declines across the globe has increased (Orth et al. 2006, Waycott et al. 2009), have manipulative field studies on the 
effects of macroalgal blooms on seagrass begun to accumulate. These studies have shown macroalgal mats can harm seagrasses by competing for light and creating unfavorable biogeochemical conditions such as anoxia, high sulfide concentrations, and toxic ammonium concentrations (Short \& Burdick 1995, Terrados et al. 1999, Hauxwell et al. 2001, McGlathery 2001, Brun et al. 2003, Holmer \& Nielsen 2007). These conditions lead to reduced seagrass growth, shoot density, and biomass (Holmquist 1997, Hauxwell et al. 2001, Nelson \& Lee 2001, Deegan et al. 2002, Brun et al. 2003, Cummins et al. 2004, Irlandi et al. 2004), although there is also some evidence of positive effects of macroalgae on seagrass (Hessing-Lewis et al. 2011). When they are healthy and abundant, seagrasses provide important habitat and ecological services to coastal areas (Costanza et al. 1997), so the potential consequences of macroalgal blooms for coastal ecosystems are significant.

Most of the experimental field studies on the effects of macroalgal blooms on seagrass communities have focused on the short-term, acute effects of blooms, with an average (and median) study duration of 3 mo (Holmquist 1997, Hauxwell et al. 2001, Nelson \& Lee 2001, Brun et al. 2003, Cummins et al. 2004, Irlandi et al. 2004, Huntington \& Boyer 2008) (but see Hessing-Lewis et al. 2011). The majority of these studies has been conducted in locations that were eutrophic due to nutrient loading from terrestrial sources. Eutrophication can directly affect seagrasses in addition to the effects of increased macroalgae (Burkholder et al. 1992). These eutrophic locations are often continuously occupied by macroalgae (Hauxwell et al. 2001, 2003). However, algal blooms also develop seasonally and affect seagrass beds in the absence of extreme eutrophic conditions (Nelson \& Lee 2001, Huntington \& Boyer 2008, Hessing-Lewis et al. 2011), and the dynamics and impacts of these blooms may not be predictable based on studies of eutrophic regions. We can advance our understanding of the consequences of these seasonal blooms, as well as eelgrass resilience and recovery, through a 2-pronged approach: using interannual variation in the size and duration of blooms as a natural experiment, complemented by controlled manipulations over multiple years.

In the northeastern Pacific region, significant interannual variation in the intensity of blooms occurs in some locations (Nelson et al. 2003, Hessing-Lewis et al. 2011), but it is not known to what extent this variation correlates with its effects on seagrass. Interand intra-annual variation in nutrients due to upwelling conditions could alter nutrient supply for blooms (Nelson et al. 2003). Changes in cloud cover associated with coastal fog can affect light levels, both of which could cause interannual variation in macroalgae even in the absence of human activities (Pregnall \& Rudy 1985). Here we assess the degree to which the timing and magnitude of ephemeral, green macroalgal blooms (Ulva sp.) vary seasonally and interannually in Bodega Bay, California, and determine how natural and experimentally augmented Ulva abundance affects eelgrass Zostera marina. Specifically, we measured Ulva abundance and seagrass shoot density, biomass, growth rate, epiphyte load, and sediment organic content in 4 treatments: (1) unmanipulated control plots, (2) fenced plots kept free of Ulva, (3) fenced plots with ambient amounts of Ulva, and (4) fenced plots with $2 \times$ ambient Ulva. Our manipulations and monitoring continued over 38 mo (including 4 summers) that varied dramatically in peak Ulva biomass (2004 to 2007), allowing us to test how the effects of Ulva on eelgrass varied interannually and to track recovery as well as loss of eelgrass biomass.

\section{METHODS}

The 4 treatments were conducted within a large, eelgrass Zostera marina meadow spanning the low intertidal to shallow subtidal in Bodega Bay harbor, California $\left(38^{\circ} 19^{\prime} \mathrm{N}, 123^{\circ} 03^{\prime} \mathrm{W}\right)$ from June 2004 to September 2007. The harbor area $\left(\sim 3.5 \mathrm{~km}^{2}\right)$ is flushed for the most part on each tidal cycle, with the possible exception of the most interior portions which appear to have some retention over a maximum of a few days based on observations of water temperature (J. Largier pers. comm.). The harbor receives little freshwater input outside of the winter rainy season (November to April), resulting in a fairly narrow salinity range close to full-strength seawater, and water temperature is generally close to the ocean temperature $\left( \pm 5^{\circ} \mathrm{C}\right)$. Native to the area, Ulva occurs on the mudflat and in intertidal and subtidal eelgrass beds, particularly in the summer months. We identified this as Ulva lactuca (Gabrielson et al. 2004), but species-level distinctions are complicated by considerable morphological plasticity. In light of this, we refer to the green ulvoid macroalgae we studied as Ulva sp. denoted as Ulva hereafter. The harbor also contains large expanses of continuous eelgrass meadow, as well as some smaller, isolated patches. We conducted the experiment within the largest continuous eelgrass bed that covers $\sim 0.3 \mathrm{~km}^{2}$, located in the southeast portion of the harbor. 


\section{Experimental design}

The experiment consisted of (1) an unmanipulated, unenclosed control and 3 Ulva treatments in which we manipulated the density of Ulva in $3 \mathrm{~m}$ diameter plots: (2) Ulva removal, (3) ambient Ulva, and (4) double-ambient Ulva (' $\left.2 x^{\prime}\right)$. The 3 manipulated treatments each had plastic fencing encircling them to a height of $1.5 \mathrm{~m}(5 \times 5 \mathrm{~cm}$ mesh opening with $1 \mathrm{~mm}$ strand thickness) that was secured to PVC poles driven into the sediment. The control plots were marked with PVC poles, but were not enclosed with fencing. Plots were arranged into blocks based on spatial proximity. Each block had 4 plots and each plot within a block was randomly assigned to one of the 4 treatments. Blocks 1 to 4 were placed in a shallow area ('Site A', 0.1 m mean low low water [MLLW]), and Blocks 5 to 8 were slightly deeper ('Site B', $-0.3 \mathrm{~m}$ MLLW). There were a total of 8 blocks (replicates) at the onset of the experiment, but Block 1 was abandoned in August 2005 when changes in bathymetry of the mudflat caused it to be shallower than at the start of the experiment, resulting in the death of eelgrass in all 4 plots. We therefore sampled 28 plots with $\mathrm{n}$ $=7$ for each treatment. Prior to applying treatments, we measured shoot density and reproductive shoot density to detect any initial differences in eelgrass abundance among plots.

Since the control plots were not enclosed by fencing, Ulva was free to drift in and out, and the density of Ulva in these plots was taken to be representative of the ambient density in the eelgrass meadow. To measure Ulva density, we collected Ulva in onefourth of each plot (1.6 $\mathrm{m}^{2}$ sampling area) and dripdried it until no more water dripped out before weighing. We calculated mean Ulva density across the control plots within the site (i.e. Blocks 2 to 4 for the shallow site and Blocks 5 to 8 for the deeper site), then used these densities as the treatment levels for the caged ambient Ulva treatments at each site. The ambient densities were doubled for the $2 \times$ treatment levels, and all Ulva was collected from the removal plots and deposited outside of the study area. During times of year when Ulva was present in the eelgrass meadow, we measured and adjusted Ulva densities in the treatments approximately every $2 \mathrm{wk}$. All plots were disturbed to the same degree during Ulva manipulation.

Although open on top, the enclosure fences provided an effective barrier to the movement of Ulva into or out of the plots, maintaining the approximate levels of Ulva density between adjustments. To assess whether caging Ulva in a single location resulted in more stationary mats than in unfenced areas, we conducted an Ulva tracking study in which we marked 12 Ulva sheets of various sizes with flagging tape and observed movement over a 2 wk period from 11 to 25 September 2007, a period in which tidal height ranged from 0 to $1.7 \mathrm{~m}$, representing the range of conditions experienced during the summer bloom season.

\section{Response variables}

To assess the effect of Ulva on eelgrass, we measured shoot density, shoot biomass, reproductive shoot density, and epiphyte load quarterly from October 2004 to August 2007. Within each circular plot, we established a $2 \times 2 \mathrm{~m}$ grid comprised of 100 quadrats of $20 \times 20 \mathrm{~cm}$. The square grid touched the edge of the circle at 4 points; these 4 quadrats were not used for sampling to avoid edge effects. During each sampling, 3 quadrats were randomly selected. Prior to destructively sampling the quadrats, we measured the growth of 2 eelgrass shoots by punching a small hole in the base of each shoot and measuring the distance it had grown after 2 wk (Zieman \& Wetzel 1980). At that time, above-ground biomass of all shoots in the 3 quadrats was collected, placed in plastic bags, and brought to the laboratory for processing. Shoots were counted to determine shoot density and then dried and weighed to determine biomass per shoot. We measured epiphyte load (which consisted mainly of microalgae) on all blades from 2 shoots in each quadrat (see Fig. S5 in the supplement at www.int-res.com/articles/suppl/m468 p107.pdf). Where the randomly chosen quadrats had no shoots, shoot density and biomass were recorded as zero, and those quadrats were excluded from the shoot growth and epiphyte load analyses. Only above-ground eelgrass biomass was collected to avoid disrupting the sediment and to minimize impact on adjacent quadrats that would be sampled on future dates. Individual quadrats were only sampled once during the experiment.

We measured sediment organic content from spring 2005 to winter 2007 to assess whether Ulva treatment had any affect (see Fig. S6 in the supplement). To assess whether Ulva reduced light, we used light sensors (Hobo pendant temperature and light data loggers, Onset Computer Company) to measure light intensity every half hour in an ambient Ulva and an Ulva removal plot during peak Ulva biomass in September 2007. 


\section{Environmental factors and Ulva biomass}

In an attempt to understand what may be driving the interannual variation in Ulva biomass, we obtained data for light availability and rainfall taken at Bodega Marine Laboratory (University of California Davis 2008) and upwelling indices from the Pacific Fisheries Environmental Laboratory (Pacific Fisheries Environmental Laboratory 2012) for the period covering our experiment. We plotted Ulva biomass against the environmental parameters and ran correlations to detect any patterns (see Figs. S1 to S3 in the supplement for more details).

\section{Statistical analyses}

We used repeated-measures ANOVA to assess the effect of Ulva treatment, site, and date on shoot density, shoot biomass, and sediment organic content data. Shoot biomass data was square-root transformed to adjust for non-normality and heteroscedasticity. Where this resulted in a significant treatment or date-by-treatment effect (in the case of shoot density and shoot biomass), we also conducted univariate ANOVAs for each date, applying a Bonferroni correction that adjusted the critical p-value to 0.004 . For those sampling dates that had a significant treatment effect, we used Tukey's honestly significant difference (HSD) post hoc test for multiple comparisons of treatments. Because it was not possible to measure shoot growth or epiphyte load for quadrats that had no shoots (i.e. quadrats in which shoot density was zero), the datasets for these response variables were unbalanced, which precluded us from using repeated-measures ANOVA. Instead we used an ANOVA model that accounted for possible non-independence of the measurements for each sampling unit (plot) over time. This approach used a linear mixed-effects model with fixed effects for sampling date site, treatment, and their interactions; it also included block nested in site and cage nested in block and site, both as random effects. To alleviate concerns of using different statistical models to test different variables, we examined patterns of shoot density with both models; both analyses reached identical conclusions. Given that reproductive shoots only occurred during spring and summer and densities in the sampling quadrats were very low (i.e. rare), we used the same mixed effects model but specified a Poisson distribution. All analyses were performed using the JMP statistical software Version 7.

\section{RESULTS}

\section{Seasonal and interannual variation in control plots}

We used eelgrass Zostera marina and Ulva biomass data collected from control plots to describe intraand interannual patterns of eelgrass and Ulva abundance and to provide context for interpreting the results of experimental manipulations.

All years showed distinct seasonal variation in Ulva abundance, with peak abundance during the summer months, although the magnitude of the blooms varied dramatically among years (Fig. 1). The largest bloom occurred in 2006, with peak density 2 times higher than the moderate blooms in 2004 and 2007, and >4 times higher than the smallest bloom in 2005. The onset and duration of Ulva blooms also varied among years: in 2004 and 2005

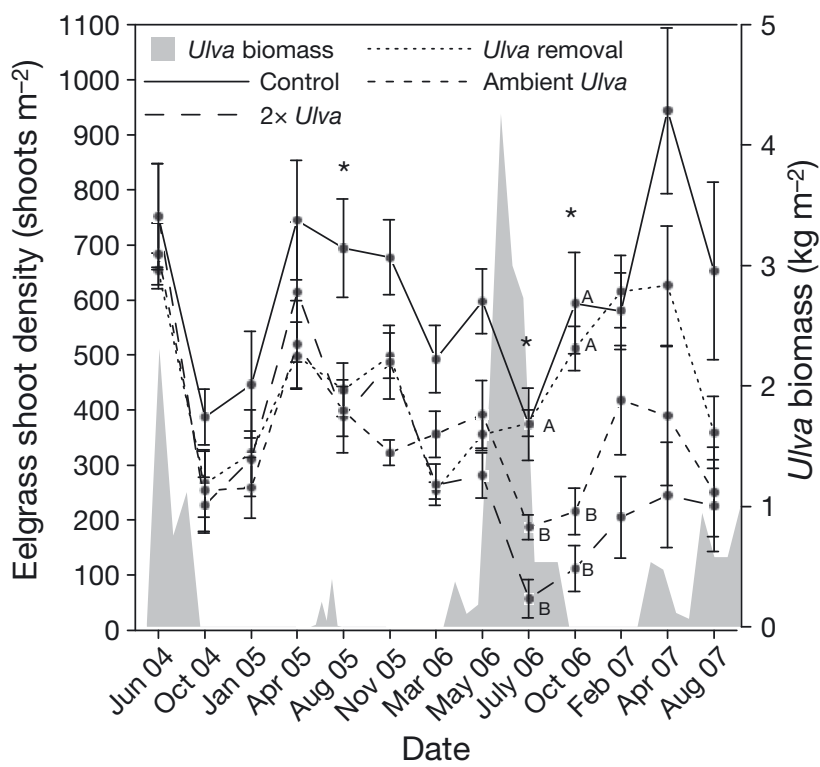

Fig. 1. Ulva biomass and Zostera marina shoot density. Ulva biomass was highest in summer 2006, which caused declines in eelgrass shoot density. The sampling dates during which there was a significant effect of Ulva treatment are marked with * (based on repeated-measures ANOVA). Within each sampling date, different letters distinguish significantly different treatments. In July 2006, shoot densities in the ambient and $2 \times$ treatments were, respectively, 50 and $85 \%$ lower than in the Ulva removal treatment. This effect continued through October 2006. In February 2007, shoot density in the ambient treatment was still lower than that in the Ulva removal treatment, although this was not significant when compared to Bonferroni-corrected p-values. Shoot density in the $2 \times$ treatment remained lower through spring. Although shoot density in the control plots was higher than in the enclosed treatments during summer months, it experienced a similar decline (52\%) during the large Ulva bloom that was not observed during the other 3 summers of the study. Means $\pm 1 \mathrm{SE}, \mathrm{n}=7$ 
Ulva was present in the eelgrass beds from June to August, in 2006 and 2007 Ulva appeared in the eelgrass beds starting in March and was present until late fall. Plots and correlations of environmental variables (light availability, upwelling, and rainfall) with Ulva biomass did not reveal any significant environmental correlates of the interannual variation (Figs. S1 to S3 in the section 'Environmental factors and Ulva biomass' of the supplement); however, because we only had 38 mo of data, our power to detect associations may have been low.

To determine the degree to which Ulva sheets moved around in the eelgrass beds, we conducted an Ulva tracking study. After $2 \mathrm{wk}$, only 1 piece of Ulva out of 12 moved from its original position, and that piece moved $<0.5 \mathrm{~m}$. Although some floating mats were observed on the surface at high tide when Ulva was abundant, the majority of Ulva within the eelgrass beds remained within the eelgrass canopy due to a combination of it being negatively buoyant, becoming entangled among the eelgrass shoots, and becoming attached to eelgrass blades and the sediment surface by tube-building polychaetes and amphipods. These interactions among Ulva and invertebrates can prevent Ulva sheets from being moved by currents and tidal flux (Reise 1983, Thomsen \& McGlathery 2005), at least over time spans of days to weeks.

For most of the experiment, eelgrass shoot density varied seasonally as has previously been described for populations not influenced by algal blooms (Duarte et al. 2006, Walker et al. 2006), with peak densities in the summer and lowest in the winter (Fig. 1). The one exception to this pattern occurred in 2006, the year of highest Ulva abundance. During the summer of 2006, Ulva wet mass exceeded $4 \mathrm{~kg}$ $\mathrm{m}^{-2}$, and eelgrass shoot density in the control plots decreased $33 \%$ from what it was in the spring (when typically it would increase by 55 to $65 \%$ from spring to summer). In the summer of 2006, shoot density was $52 \%$ lower than that observed in the other 3 summers of the study when Ulva was less abundant (Fig. 1).

\section{Ulva manipulation}

There were strong effects of Ulva biomass on eelgrass density and biomass, but no effects on shoot growth, reproductive shoot density, epiphyte load, and sediment organic content. Prior to discussing each of these, we outline the effects of caging to provide context for the main effects.

\section{Effects of mesh enclosures}

We found significant differences between the unenclosed control and the enclosed ambient treatment during the spring, summer, and fall sampling dates. Shoot density in the unenclosed control was significantly higher than in the 3 enclosed treatments in August 2005 (when Ulva was scarce), and, in 2006, shoot density in the control was significantly higher than in the ambient and $2 \times$ Ulva treatments, but not than in the Ulva removal treatment (Fig. 1). These differences are most likely due to shading or reduction in flow caused by the mesh fences. It is unlikely that restricting Ulva movement caused the differences, since the tracking study showed that, Ulva does not move much in eelgrass beds. There were no significant differences in shoot biomass (Fig. 2), shoot growth (Fig. 3), reproductive shoot density (Fig. S4 in the supplement), epiphyte load (Fig. S5 in the supplement), or sediment organic content (Fig. S6 in the supplement) between the enclosed ambient treatment and unenclosed control plots.

\section{Eelgrass shoot density}

The repeated-measures ANOVA showed a significant effect of Ulva treatment on shoot density $\left(F_{(3,15)}=3.89, \mathrm{p}<0.0001\right)$, but there was no significant effect of site $\left(F_{(1,15)}=0.047, \mathrm{p}=0.41\right)$, nor was there a significant site $\times$ treatment interaction $\left(F_{(3,15)}\right.$ $=0.17, \mathrm{p}=0.50$ ). There were 3 sampling dates (out of a total of 12) during which Ulva treatment significantly altered eelgrass density: August 2005, and July and October 2006 (Fig. 1). The treatment effects in August 2005 were caused by differences between the control and the 3 enclosed treatments (Ulva removal, ambient, and $2 \times$ ), discussed above. There were no significant differences among the 3 manipulated treatments until the large bloom in 2006, when Ulva peaked at $4 \mathrm{~kg} \mathrm{~m}^{-2}$ (Fig. 1), although Ulva was present during the summer in 2004 and 2005. In July 2006, after the peak of the bloom, there was a significant effect of Ulva treatment on shoot density (ANOVA, $F_{(3,3)}=17.59, \mathrm{p}<$ $0.0001)$. Shoot density in the ambient and $2 \times$ treatments was significantly reduced (50 and 85\%, respectively) compared to the Ulva removal treatment (Tukey's test, p $<0.05$; Fig. 1).

In October 2006, 4 mo after the bloom peaked, shoot density in the ambient Ulva and $2 \times$ Ulva treatments remained lower than that in the Ulva 
removal treatment and unmanipulated control (ANOVA, $F_{(3,3)}=21.48, \mathrm{p}<0.0001$; Tukey's test, $\mathrm{p}<$ 0.05). In February 2007, shoot density in the ambi-
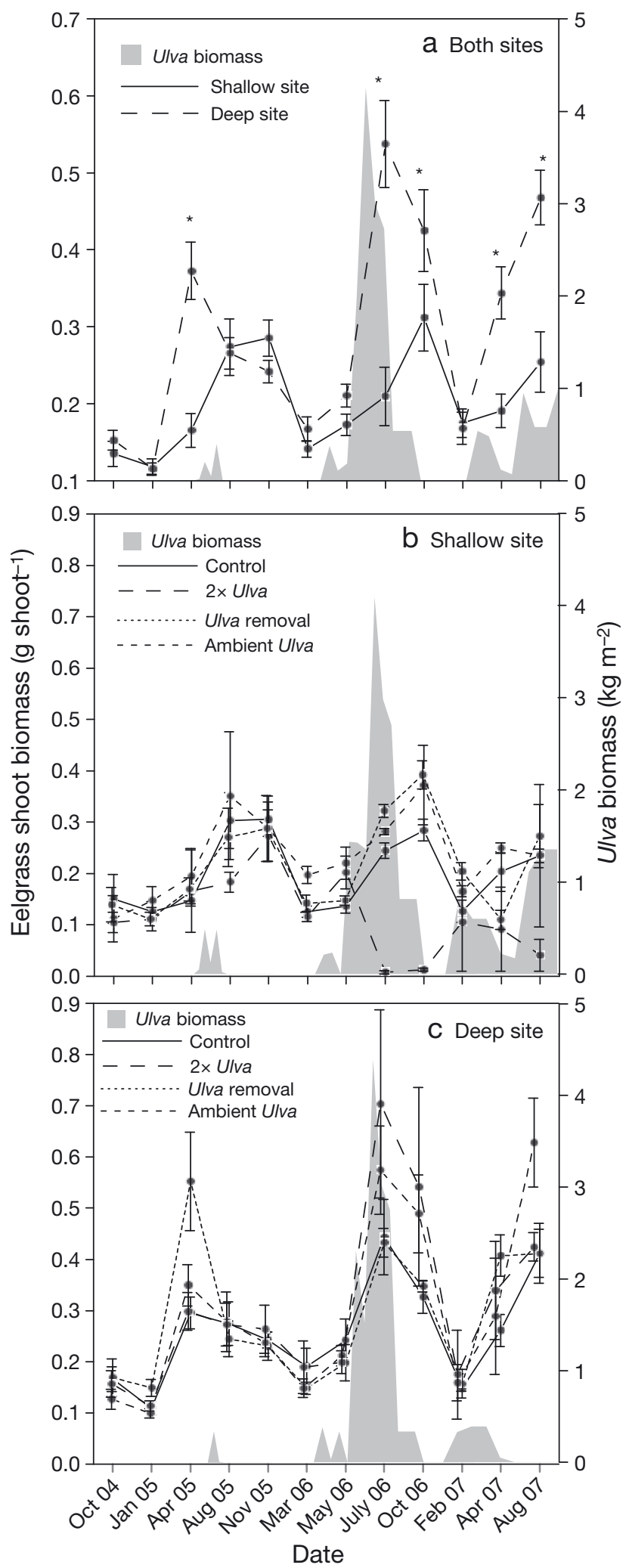

ent and $2 \times$ treatments were still lower than that in the Ulva removal treatment, although this was not significant when compared with the Bonferronicorrected critical value of 0.004 (ANOVA, $F_{(3,3)}=$ 5.08, $\mathrm{p}=0.013$; Tukey's test, $\mathrm{p}<0.05)$. By April 2007, 10 mo after the large bloom, the differences among all 3 Ulva manipulation treatments were no longer statistically significant (ANOVA, $F_{(3,3)}=6.67$, $\mathrm{p}=0.004$; Tukey's test, $\mathrm{p}>0.05$ ) (Fig. 1), although similar absolute magnitude differences persisted until summer 2007.

Although shoot density was higher in the control plots compared to the enclosed treatments during the summer and fall months, it followed the same seasonal pattern and experienced a similar decline in shoot density during the large Ulva bloom in 2006. In July 2006, shoot density in the control plots was $52 \%$ lower than summer densities in the same plots during the other 3 summers of the study, which is the same magnitude of decline in shoot density observed between the Ulva removal and ambient treatments for July 2006 (50\%; Fig. 1). Thus, despite caging effects, we do not see any evidence that the effects of Ulva were exacerbated by the presence of cages, only that baseline levels of eelgrass were lower in caged treatments.

\section{Eelgrass shoot biomass}

The repeated-measures ANOVA showed an effect of Ulva treatment on biomass per shoot $\left(F_{(3,15)}=5.60\right.$, $\mathrm{p}=0.008$ ) (Fig. 2a), as well as an effect of site $\left(F_{(1,15)}=93.84, \mathrm{p}<0.0001\right)$, a site $\times$ treatment interaction $\left(F_{(3,15)}=8.39, \mathrm{p}=0.0016\right)$, and a date $\times$ site $\times$ treatment interaction $\left(F_{(33,165)}=2.28, \mathrm{p}=0.01\right.$, Greenhouse-Geisser epsilon $=0.448$ ). The sampling dates with significant site $\times$ treatment interactions all occurred during the summers when Ulva was abundant (2006 and 2007); during these sampling dates the $2 \times$ treatment of Ulva reduced per-shoot biomass at the shallow but not the deep site (Fig. 2b,c). In the spring and summer of 2005 to 2007, shoot biomass tended to be greater in the deep site (Fig. 2).

Fig. 2. Ulva biomass and Zostera marina shoot biomass. There were significant effects of date, site, and treatment, and a significant 3-way interaction among them. (a) Eelgrass shoot biomass by site and Ulva biomass (averaged across both sites). In the spring and summer of all years, shoot biomass was greater at the deep site. (b) Eelgrass shoot biomass by treatment and Ulva biomass at the shallow site. (c) Eelgrass and Ulva biomass at the deep site. Means $\pm 1 \mathrm{SE}, \mathrm{n}=7$ 


\section{Eelgrass shoot growth}

There was no significant effect of Ulva on shoot growth $\left(F_{(3,22)}=0.40, \mathrm{p}=0.75\right)$ (Fig. 3a). There was a significant effect of site $\left(F_{(1,5)}=19.29, \mathrm{p}=0.006\right)$ and a significant date $\times$ site interaction $\left(F_{(11,220)}=3.85, \mathrm{p}<\right.$ 0.001), with shoots in the deep site growing faster than those in the shallow site for some of the sampling dates (Fig. 3b). Growth was generally higher in the spring and summer, and growth at the shallow site never exceeded that at the deep site.

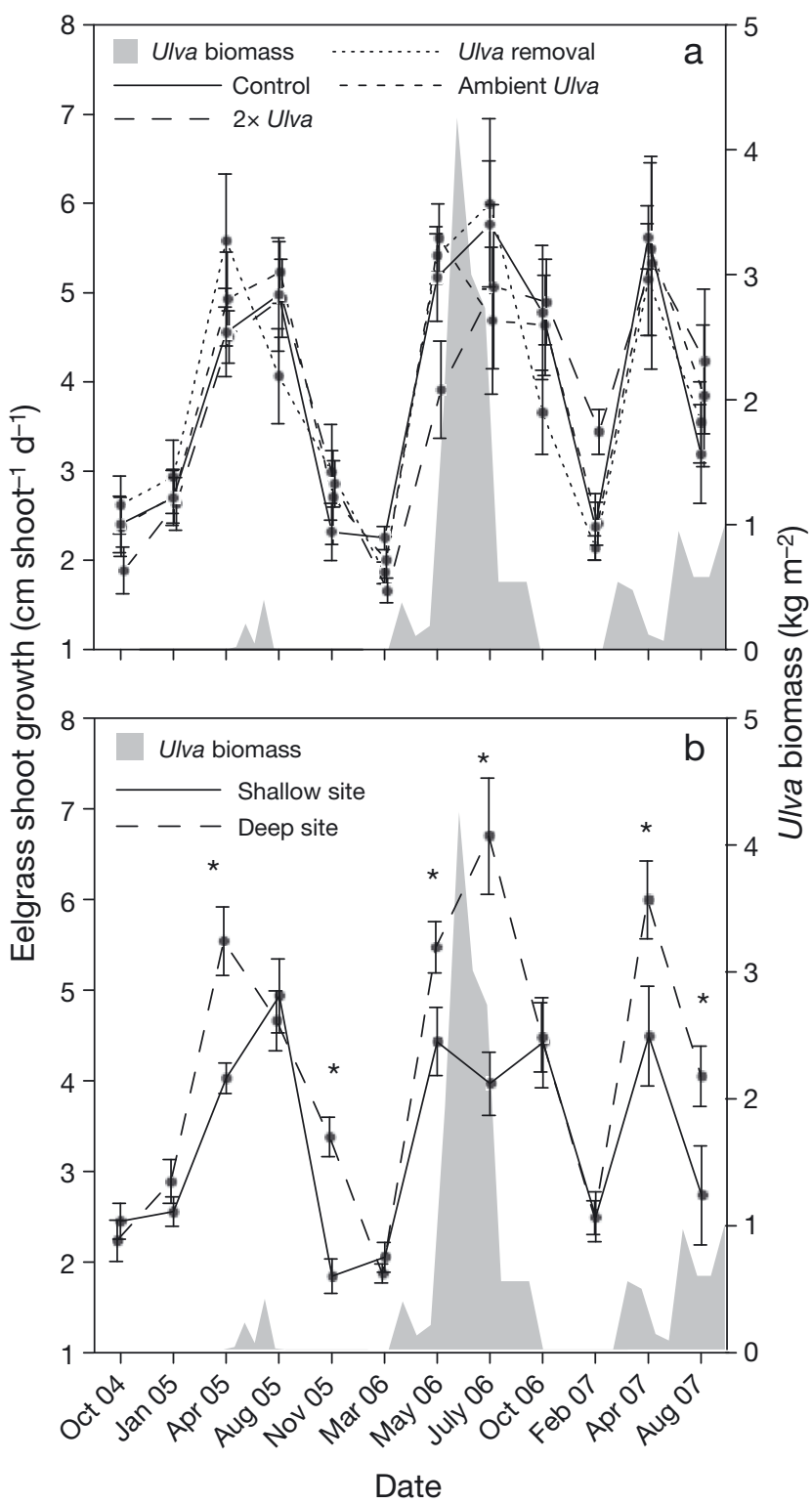

Fig. 3. Ulva biomass and Zostera marina shoot growth. (a) Shoot growth was similar among all treatments across all sampling dates. (b) The deep site had faster growth during the spring and early summer. Means $\pm 1 \mathrm{SE}, \mathrm{n}=7$
Eelgrass reproductive shoot density, epiphyte load, and sediment organic content

There were no significant treatment or site effects for reproductive shoot density (treatment: $\chi^{2}<$ 0.0001, prob $>\chi^{2}=1.0$; site: $\chi^{2}<0.0001$, prob $>\chi^{2}=$ 0.99) (Fig. S4 in the supplement). Nor were there any effects of treatment or site on epiphyte load (treatment: $F_{(3,203)}=0.92, \mathrm{p}=0.43$; site: $F_{(1,5)}=5.29, \mathrm{p}=$ 0.07 ) (Fig. S5 in the supplement). The repeated-measures ANOVA showed no significant effect of treatment or site on sediment organic content (treatment: $F_{(3,11)}=0.54, \mathrm{p}=0.67 ;$ site: $\left.F_{(1,11)}=0.79, \mathrm{p}=0.39\right)$ (Fig. S6 in the supplement).

\section{Effects of Ulva on light intensity}

The measurements of light intensity in the ambient and Ulva removal treatments in September 2007 showed light was lower under the ambient level of Ulva, which at the time was $1 \mathrm{~kg} \mathrm{~m}^{-2}$ (matched pairs analysis: $\left.t_{(360)}=7.16, \mathrm{p}<0.0001\right)$. Integrating over the $2 \mathrm{wk}$ period, Ulva reduced light by $46 \%$. During the

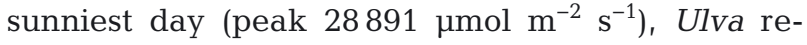
duced light by an average of $64 \%$, while on the lowest light day (peak $1642 \mu \mathrm{mol} \mathrm{m} \mathrm{m}^{-2} \mathrm{~s}^{-1}$ ) by $42 \%$.

\section{DISCUSSION}

In our 38 mo study, magnitude, duration, timing, and effects of Ulva blooms varied dramatically among years. Had we conducted the experiment in 2004, 2005, or 2007 only, we would have concluded that Ulva has little effect on the eelgrass Zostera marina in Bodega Bay. However, during the largest bloom in the summer of 2006, the peak Ulva density was 8 times that of the previous year, and the bloom started earlier and ended later than in the other years of the study. It was only during this year that we found significant and large effects of Ulva on eelgrass. A $50 \%$ reduction in eelgrass density persisted for 4 to 6 mo following the peak of the bloom, and biomass per shoot also declined. However, even in this extreme year, Ulva did not alter growth rates of existing shoots, so effects on density appear to be due to shoot mortality and reduced production of new shoots (either via clonal or sexual reproduction). We discuss these effects and their underlying mechanisms and implications in more detail below.

Two comparisons provide evidence for the effects of Ulva on shoot density: (1) correspondence among 
years between high Ulva biomass and decreased eelgrass shoot density (Fig. 1) and (2) the differences among the 3 enclosed, manipulated treatments within the large bloom of 2006 (Fig. 1). Although enclosures themselves reduced shoot density, the effect caused by the 2006 Ulva bloom was remarkably similar across the control and manipulated plots, i.e. $50 \%$ reduction in shoot density, despite different starting densities (Fig. 1). This is also similar to the $54 \%$ reduction in shoot density caused by another ulvoid, Ulvaria obscura, over a period of $5 \mathrm{wk}$ in Washington (Nelson \& Lee 2001). However, the ambient treatment took between 4 and $7 \mathrm{mo}$ to return to the pre-bloom density compared to $<3$ mo for the control. Higher light or flow levels in unenclosed plots may have enhanced vegetative recruitment of new shoots (Hauxwell et al. 2001).

The immediate results from the large bloom of 2006 are similar to single-season studies that have examined the effects of intense macroalgal blooms on eelgrass, in that there were negative effects on shoot density. In studies on systems ranging from highly eutrophic (Waquoit Bay, Massachusetts) to less-impacted (Tomales Bay, California) (Nelson \& Lee 2001, Hauxwell et al. 2003, Huntington \& Boyer 2008), macroalgal mats cause senescence of existing eelgrass shoots or impede the recruitment of new shoots. Some studies have also shown negative effects of macroalgae on eelgrass shoot growth (Hauxwell et al. 2001, Brun et al. 2003, Holmer \& Nielsen 2007, Huntington \& Boyer 2008), while others have not (Hauxwell et al. 2003). In their study on the effects of Ulva rigida on Zostera noltii, Brun et al. (2003) suggest different explanations for the lack of a significant effect on growth, including a net transfer of dissolved organic carbon from $U$. rigida to $Z$. noltii that would help to offset reduced photosynthesis, as well as a mobilization of non-structural carbohydrates in both the above- and belowground tissues of $Z$. noltii to meet carbon demands. The effects of macroalgae on other species of seagrasses similarly find variation in the intensity of response (Holmquist 1997, Maciá 2000, Cummins et al. 2004, Irlandi et al. 2004). It is not clear whether the inconsistencies in these results are due to the response of different seagrass species or to differences in the stress caused by different macroalgal species, or some environmental factor such as light, temperature, or water flow.

This experiment failed to detect an effect of Ulva on 3 other response variables we measured: epiphyte loads, reproductive shoot production, and sediment organic content, suggesting that other factors drive these variables or that the scale of our manipulation was not sufficient to affect these variables. (1) Prior to the study, we hypothesized that shading by Ulva would reduce epiphyte loads on eelgrass, as has been shown in other cases (Irlandi et al. 2004). However, we did not find any evidence of this, nor did we find any effect of site on epiphyte load despite the additional light attenuation from the water column at the deeper site. This suggests other factors are driving epiphyte abundance on eelgrass at this location, such as invertebrate grazing (Hughes et al. 2010). Ulva only had strong effects on invertebrate abundance and diversity during the large bloom in 2006, when it increased the density of gammarid amphipods (Olyarnik 2008). (2) Although there is some evidence that eelgrass reproductive output may increase in response to stress (Harwell \& Rhode 2007), we failed to find an effect of Ulva on eelgrass reproductive shoot density. Reproductive shoot production in this population is relatively small overall $(10 \%$ or less of all shoots are reproductive during the summer months), and we may not have conducted the experimental manipulation at a large enough scale to pick up small differences in reproduction that Ulva may cause. (3) Although large amounts of Ulva biomass senesced, became buried under sediments, and decomposed in the eelgrass beds during the summer and fall months, we found no effect of Ulva treatment on sediment organic content. This is most likely because Ulva is highly labile and breaks down quickly ( $>90 \%$ of initial mass decomposes within $7 d_{i}$ R. J. Best \& S. V. Olyarnik unpubl. data).

\section{Mechanisms}

One of the most obvious mechanisms leading to negative effects of macroalgal blooms on seagrasses is shading. Macroalgal canopies can cause chronic, severe light limitation to seagrasses, especially for small, newly recruiting shoots (Huntington \& Boyer 2008). Although the results from this study show growth of established shoots in Ulva removal treatments does not differ from that under macroalgal cover (the shoots grow at the same rate), Hauxwell et al. (2003) suggest that shoots that are subject to macroalgal cover lack sufficient resources to translocate energy to newly recruiting clonal branches. This may be caused by competition for light and nutrients as well as reduced gas exchange, all factors 
that can be exacerbated by reductions in flow caused by the additional habitat structure of macroalgae (Nelson \& Lee 2001). Additional negative effects may occur via unfavorable biogeochemical conditions imposed on belowground eelgrass structures, such as anoxia (Pregnall et al. 1984), high sulfide concentrations, and other redox changes resulting from low oxygen (Terrados et al. 1998), toxic ammonium concentrations (van Katwijk et al. 1997), and physical damage (Valdemarsen et al. 2010). These effects are likely to be more severe for newly recruiting than for established shoots (van Katwijk et al. 1997).

\section{Bloom size, timing, and duration}

Results from the $2 \times$ treatment suggest that blooms larger than what occurred in 2006 will have a more severe and longer lasting impact on eelgrass. Although we saw a bloom of this size in only 1 of 4 summers, they are not exceedingly rare. In the year after this study was completed (2008) there was another bloom similar in size to that of 2006 (S. Olyarnik unpubl. data), and, in unrelated experiments, shoot density declined in the summer of 2008 coincident with this bloom (Hughes \& Stachowicz 2011). In 2006 shoot density in the $2 \times$ treatment decreased by $85 \%$ compared to the $50 \%$ reduction in the ambient treatment, and the effect continued for $>6$ mo, longer than in the ambient treatment. Although some reductions in shoot density may alleviate intra-specific competition for light and nutrients, large declines in shoot density can lead to sediment re-suspension and increased turbidity (Hasegawa et al. 2008), i.e. additional stresses that can cause further eelgrass decline (McGlathery 2001, Walker et al. 2006).

Also, the timing and duration of blooms are likely to be important. Blooms that continue into the fall prevent eelgrass recovery prior to the winter season, which is likely to affect the ability to acquire carbohydrate reserves that are important for winter survival and spring growth in this perennial species (Hemminga \& Duarte 2000). If large Ulva blooms were to occur in consecutive years, this might reduce the recovery of eelgrass and could reduce shoot density to precariously low levels.

\section{Interannual variation of UIva blooms}

Green macroalgal blooms have been linked to nitrogen loading from anthropogenic sources in more eutrophic systems that are heavily influenced by terrestrial runoff (Valiela et al. 1997) and to severe impacts on eelgrass. However, evidence is mounting that the eutrophication paradigm does not hold true for estuaries adjacent to upwelling zones (Kentula \& DeWitt 2003, Nelson et al. 2003, Hessing-Lewis et al. 2011). Although large increases in terrigenous nutrients could potentially increase the size and frequency of algal blooms, we did not find any correlation that suggested rainfall events (which could deliver nutrients via runoff) are driving the interannual patterns of Ulva. In 2007, we conducted smallscale, manipulative experiments in which we crossed the presence of grazers with a fertilization treatment and found that neither of these factors affected Ulva biomass dramatically (Olyarnik 2008). Instead, major differences in growth of Ulva throughout a growing season correlated well with light availability (PAR), which is influenced by coastal fog (Pregnall et al. 1984). However, when we examined light availability and Ulva biomass from 2004 to 2007, we did not detect any pattern or correlation that would explain the large variability in Ulva from year to year. Similarly, we did not find any correlation between upwelling and Ulva. It should be noted that, while relatively long-term compared to other studies of macroalgal blooms, our study comprises only 4 summer blooms and thus is limited in its power to detect drivers of interannual Ulva biomass, especially if a number of interacting factors causes high variability in blooms.

Strong interannual variation in the timing, duration, and magnitude of macroalgal blooms can dramatically alter the effects of blooms on seagrasses, urging caution in the extrapolation of studies that focus on a single year without providing context for how that year compares to mean conditions. Our 38 mo study showed that a large Ulva bloom had dramatic, negative effects on eelgrass density that persisted for several months, but eelgrass recovered prior to the next bloom season. The small magnitude of blooms in the 2 yr prior to the severe bloom in 2006 may have contributed to the resilience of the eelgrass in our study and reduced community level effects, and the effects of consecutive years of large blooms may be more persistent. These blooms appear to be a natural seasonal component of this ecosystem, although it is unclear what factors are driving the variation. Further investigations across additional years may help link environmental and perhaps biological drivers with bloom magnitude and allow stronger predictions of bloom intensity and effects on seagrass ecosystems. 
Acknowledgements. We thank R. Hughes, A. Larson, K. Aquilino, J. Byrnes, and K. Hammond for field assistance and input, A. Tasoff for laboratory help, S. Williams and T. Grosholz for guidance, and J. Braun for statistical advice. We acknowledge Bodega Marine Laboratory and Reserve for financial and logistical support, and Doran Regional Park for site access. This work was supported by grants to S.V.O. from the University of California Davis, the National Science Foundation, and the Center for Population Biology at UC Davis.

\section{LITERATURE CITED}

> Brun FG, Vergara JJ, Navarro G, Hernandez I, PerezLlorens JL (2003) Effect of shading by Ulva rigida canopies on growth and carbon balance of the seagrass Zostera noltii. Mar Ecol Prog Ser 265:85-96

Burkholder JM, Mason KM, Glasgow HB Jr (1992) Watercolumn nitrate enrichment promotes decline of eelgrass Zostera marina: evidence from seasonal mesocosm experiments. Mar Ecol Prog Ser 81:163-178

> Cardoso P, Pardal MA, Lillebo AI, Ferreira S, Raffaelli D, Marques JC (2004) Dynamic changes in seagrass assemblages under eutrophication and implications for recovery. J Exp Mar Biol Ecol 302:233-248

Costanza R, D'Arge R, de Groot R, Farber S and others (1997) The value of the world's ecosystem services and natural capital. Nature 387:253-260

Cummins SP, Roberts DE, Zimmerman KD (2004) Effects of the green macroalga Enteromorpha intestinalis on macrobenthic and seagrass assemblages in a shallow coastal estuary. Mar Ecol Prog Ser 266:77-87

Deegan LA, Wright A, Ayvazian SG, Finn JT, Golden H, Merson RR, Harrison J (2002) Nitrogen loading alters seagrass ecosystem structure and support of higher trophic levels. Aquat Conserv 12:193-212

Diaz R, Rosenberg R (1995) Marine benthic hypoxia: a review of its ecological effects and the behavioural responses of benthic macrofauna. Oceanogr Mar Biol Annu Rev 33:245-303

Duarte CM, Fourqurean JW, Krause-Jensen D, Olesen B (2006) Dynamics of seagrass stability and change. In: Larkum AWD, Orth RJ, Duarte CM (eds) Seagrasses: biology, ecology and conservation. Springer, Heidelberg, p 271-294

Gabrielson PW, Widdowson TB, Lindstrom SC (2004) Keys to the seaweeds and seagrasses of Oregon and California, North of Point Conception. PhycoID, Hillsborough, $\mathrm{NC}$

- Harwell M, Rhode J (2007) Effects of edge/interior and patch structure on reproduction in Zostera marina L. in Chesapeake Bay, USA. Aquat Bot 87:147-154

Hasegawa N, Hori M, Mukai H (2008) Seasonal changes in eelgrass functions: current velocity reduction, prevention of sediment resuspension, and control of sediment-water column nutrient flux in relation to eelgrass dynamics. Hydrobiologia 596:387-399

Hauxwell J, Cebrian J, Furlong C, Valiela I (2001) Macroalgal canopies contribute to eelgrass (Zostera marina) decline in temperate estuarine ecosystems. Ecology 82: 1007-1022

> Hauxwell J, Cebrian J, Valiela I (2003) Eelgrass Zostera marina loss in temperate estuaries: relationship to landderived nitrogen loads and effect of light limitation imposed by algae. Mar Ecol Prog Ser 247:59-73

Hemminga M, Duarte CM (2000) Seagrass ecology. Cambridge University Press, Cambridge

Hessing-Lewis ML, Hacker SD, Menge BA, Rumrill SS (2011) Context-dependent eelgrass-macroalgae interactions along an estuarine gradient in the Pacific Northwest, USA. Estuar Coasts 34:1169-1181

- Holmer M, Nielsen RM (2007) Effects of filamentous algal mats on sulfide invasion in eelgrass (Zostera marina). J Exp Mar Biol Ecol 353:245-252

Holmquist JG (1997) Disturbance and gap formation in a marine benthic mosaic: influence of shifting macroalgal patches on seagrass structure and mobile invertebrates. Mar Ecol Prog Ser 158:121-130

Hughes AR, Stachowicz DJJ (2011) Seagrass genotypic diversity increases disturbance response via complementarity and dominance. J Ecol 99:445-453

> Hughes AR, Best RJ, Stachowicz JJ (2010) Genotypic diversity and grazer identity interactively influence seagrass and grazer biomass. Mar Ecol Prog Ser 403:43-51

Huntington B, Boyer KE (2008) Effects of red macroalgal (Gracilariopsis sp.) abundance on eelgrass Zostera marina in Tomales Bay, California, USA. Mar Ecol Prog Ser 367:133-142

> Irlandi E, Orlando B, Biber P (2004) Drift algae-epiphyteseagrass interactions in a subtropical Thalassia testudinum meadow. Mar Ecol Prog Ser 279:81-91

> Kentula ME, DeWitt TH (2003) Abundance of seagrass (Zostera marina L.) and macroalgae in relation to the salinity-temperature gradient in Yaquina Bay, Oregon, USA. Estuaries 26:1130-1141

> Lapointe B (1997) Nutrient thresholds for bottom-up control of macroalgal blooms on coral reefs in Jamaica and southeast Florida. Limnol Oceanogr 42:1119-1131

> Maciá S (2000) The effects of sea urchin grazing and drift algal blooms on a subtropical seagrass bed community. J Exp Mar Biol Ecol 246:53-67

> McClanahan TR, Sala E, Stickels PA, Cokos BA, Baker AC, Starger CJ, Jones SH IV (2003) Interaction between nutrients and herbivory in controlling algal communities and coral condition on Glover's Reef, Belize. Mar Ecol Prog Ser 261:135-147

> McGlathery KJ (2001) Macroalgal blooms contribute to the decline of seagrass in nutrient-enriched coastal waters. J Phycol 37:453-456

- Nelson TA, Lee A (2001) A manipulative experiment demonstrates that blooms of the macroalga Ulvaria obscura can reduce eelgrass shoot density. Aquat Bot 71: 149-154

> Nelson TA, Nelson AV, Tjoelker M (2003) Seasonal and spatial patterns of 'Green Tides' (ulvoid algal blooms) and related water quality parameters in the coastal waters of Washington State, USA. Bot Mar 46:263-275

Olyarnik SV (2008) The causes and consequences of macroalgal blooms on an eelgrass (Zostera marina) community in Bodega Harbor, CA. PhD dissertation, University of California Davis, Davis, CA

> Orth RJ, Carruthers TJB, Dennison WC, Duarte CM and others (2006) A global crisis for seagrass ecosystems. Bioscience 56:987-996

Pacific Fisheries Environmental Laboratory (2012) Upwelling index. Available at: www.pfeg.noaa.gov/products/ pfel/modeled/indices/upwelling/NA/upwell_menu_NA. html (accessed 28 March 2012)

Pregnall A, Rudy P (1985) Contribution of green macroalgal 
mats (Enteromorpha spp.) to seasonal production in an estuary. Mar Ecol Prog Ser 24:167-176

Pregnall A, Smith R, Kursar T, Alberte R (1984) Metabolic adaptation of Zostera marina (eelgrass) to diurnal periods of root anoxia. Mar Biol 83:141-147

Raffaelli D, Raven J, Poole L (1998) Ecological impact of green macroalgal blooms. Oceanogr Mar Biol Annu Rev 36:97-125

Reise K (1983) Sewage, green algal mats anchored by lugworms, and the effects on Turbellaria and small Polychaeta. Helgol Mar Res 36:151-162

Short FT, Burdick DM (1995) Mesocosm experiments quantify the effects of eutrophication on eelgrass, Zostera marina. Limnol Oceanogr 40:740-749

Terrados J, Duarte CM, Fortes M, Borum J and others (1998) Changes in community structure and biomass of seagrass communities along gradients of siltation in SE Asia. Estuar Coast Shelf Sci 46:757-768

Terrados J, Duarte CM, Kamp-Nielsen L, Agawin N and others (1999) Are seagrass growth and survival affected by reducing conditions in the sediment? Aquat Bot 65: 175-197

Thomsen MS, McGlathery K (2005) Facilitation of macroalgae by the sedimentary tube forming polychaete Diopatra cuprea. Estuar Coast Shelf Sci 62:63-73

University of California Davis (2008) Bodega ocean observing node. Available at: www.bml.ucdavis.edu/boon/ index.html (accessed 12 April 2012)

Editorial responsibility: Hans Heinrich Janssen, Oldendorf/Luhe, Germany
Valdemarsen T, Canal-Vergés P, Kristensen E, Holmer M, Kristiansen MD, Flindt MR (2010) Vulnerability of Zostera marina seedlings to physical stress. Mar Ecol Prog Ser 418:119-130

- Valiela I, Foreman K, LaMontagne M, Hersh D and others (1992) Couplings of watersheds and coastal waters: sources and consequences of nutrient enrichment in Waquoit Bay, Massachusetts. Estuaries 15:443-457

Valiela I, McClelland J, Hauxwell J, Behr PJ, Hersh D, Foreman K (1997) Macroalgal blooms in shallow estuaries: controls and ecophysiological and ecosystem consequences. Limnol Oceanogr 42:1105-1118

van Katwijk M, Vergeer L, Schmitz G, Roelofs J (1997) Ammonium toxicity in eelgrass Zostera marina. Mar Ecol Prog Ser 157:159-173

Walker DI, Kendrick GA, McComb AJ (2006) Decline and recovery of seagrass ecosystems - the dynamics of change. In: Larkum AWD, Orth RJ, Duarte CM (eds) Seagrasses: biology, ecology and conservation. Springer, Heidelberg, p 551-565

Waycott M, Duarte CM, Carruthers TJB, Orth RJ and others (2009) Accelerating loss of seagrasses across the globe threatens coastal ecosystems. Proc Natl Acad Sci USA 106:12377-12381

Zieman JC, Wetzel RL (1980) Productivity in seagrasses: methods and rates. In: Phillips R, McRoy C (eds) Handbook of seagrass biology: an ecosystem perspective. Garland STPM, New York, NY, p 87-116

Submitted: October 25, 2011; Accepted: August 1, 2012

Proofs received from author(s): November 3, 2012 